\title{
O futebol business: estádio moderno, torcedores e megaeventos
}

\section{Rafael Willian Clemente}

Mestre em Ciências Sociais pela Universidade Federal Rural do Rio de Janeiro - UFRRJ; Especialista em História do Brasil pela Universidade Federal Fluminense - UFF; Graduado em História pelo Centro Universitário de Volta Redonda - UniFOA); Docente I (SEEDUC/RJ); Pesquisador do Grupo de Pesquisa "Distúrbio - Dispositivos, tramas urbanas, ordens e resistências" da Universidade Estadual do Rio de Janeiro - UERJ. 


\section{Resumo}

O presente trabalho foi construído tendo a relação de torcedores de futebol no estádio como ponto principal. $\mathrm{Na}$ esteira do chamado "futebol moderno", aquele atingido diretamente pelos processos de globalização e mercantilização dos bens culturais, pretendemos identificar determinados processos e possíveis fenômenos capazes de afetar o modus torcedor. Uma das maneiras está diretamente ligada às modificações do espaço - do urbano ao lócus esportivo - propiciadas e incentivadas a partir dos grandes eventos. Sendo assim, concentramo-nos em entender as lógicas teóricas e práticas no capitalismo tardio da modernização tanto dos espaços físicos e estruturas como das relações do público com o esporte. A pesquisa de campo, etnografia, aliou-se à teoria e também aos documentos e fontes escritas para a análise final, ao menos em relação à conclusão deste trabalho, pois, em se tratando de futebol, a volatilidade do tema faz com que a bola não pare de rolar.

Palavras-chave: Torcedores de futebol. Futebol. Modernização. Megaeventos

\section{Abstract}

The present work was built having the football fans' relationship at the stadium as the main point. In the wake of the so-called "modern football", the one hit directly by the processes of globalization and commodification of cultural goods, we intend to identify certain processes and possible phenomena capable of affecting the modus supporter. One of the ways is directly linked to the modifications of space - from the urban to the sporting locus - propitiated and encouraged from the mega events. Thus, we focus on understanding the theoretical and practical logics in the late capitalism of modernization of both physical spaces, structures, and public relations with sports. The field research, ethnography, allied to the theory and also to the documents and written sources for the final analysis, at least in relation to the conclusion of this work, because in soccer, the volatility of the theme causes the ball does not stop to roll.

Keywords: Football fans. Football. Modernization. Mega events. 


\section{Introdução}

Nos últimos anos, os estudos sobre esportes no Brasil foram alavancados pela proximidade de dois grandes eventos, a Copa do Mundo de Futebol (2014) e os Jogos Olímpicos de 2016. Não por modismo, mas por oportunismo de se ter um vasto campo de pesquisa bem próximo a nós, também seguimos este caminho. Nosso tema de trabalho gira em torno da modernização capitalista ${ }^{1}$ que vem sendo realizada no "mundo do futebol", nosso recorte temático. Embora ela seja extensiva a todos os setores do esporte de alto rendimento - da mercantilização dos "pés-de-obra", jogadores, até o ambiente físico e espacial das praças onde acontecem os jogos.

Os megaeventos têm trazido ao circuito urbano - onde grande parte da estrutura espacial sofre mudanças significativas - um momento ímpar de construção, reconstrução e ressignificações das relações humanas no tocante à vivência nessas estruturas de ordem espacial. Seja por interesse do poder público local, seja por exigência das entidades que detêm a organização e controle dos acontecimentos esportivos, a cidade que abriga um megaevento recebe importantes investimentos em infraestrutura e, consideravelmente, sofre impactos ora positivos, ora negativos em seu fluxo cotidiano de vivências e sociabilidades.

Para início de análise, será importante ressaltar dois "momentos" da vida socioeconômica dos esportes que, historicamente interligados entre si, trazem a compreensão de boa parte do processo modernizante, tanto dos espaços urbanos, quanto das praças esportivas, em si.

O primeiro, a padronização estipulada pela Federação Internacional de Futebol (FIFA) onde há eventos oficiais subsidiados por essa instituição, o mais importante deles, a Copa do Mundo de Futebol. Vale ressaltar a interferência das instituições mandatárias, também chamadas de organizadoras desses eventos, nas formas e padrões de realização do esporte, suas regras, mas também nos modelos do lócus

\footnotetext{
${ }^{1} \mathrm{O}$ entendemos como um processo da ordem decorrente do capitalismo tardio onde a cultura se mercantiliza de maneira acentuada. Aos objetos culturais se unem o conforto, a tecnologia e a beleza como elementos não só estéticos, mas incentivadores do consumo. Portanto, esse processo tende a privilegiar determinados nichos, setores e espaços em detrimento de outros. No tocante ao esporte, talvez seja importante ressaltar que tal processo se concretizou após aos Jogos Olímpicos de Los Angeles (1994) quando o alto conglomerado empresarial viu nos esportes a possibilidade do business em longa escala internacional e as Olimpíadas de Barcelona (1992) no tocante a modernização aparelhos da cidade.
} 
esportivo e consequentemente na interferência nas cidades. Um modus operandi tanto da FIFA, quanto do Comitê Olímpico Internacional (COI).

O segundo momento, como um reflexo dessa tendência modernizante no futebol mundial, está ligado às relações diretas e indiretas entre os indivíduos envolvidos nos processos torcedores que, constantemente são ressignificadas, sofrem efeitos, resistem e, por vezes, tomam a direção de uma mercantilização do (no) evento, da (na) sociabilidade: A ação torcedora, por assim dizer. Ou seja, elas são transformadas pela modificação e reestruturação do espaço torcedor. Assim, entendemos que o estádio de futebol é o local de encontro desses dois pontos.

\section{O evento business: o futebol como negócio}

O futebol moderno vem trazendo consigo vultosas quantias financeiras e interesses muito diversos, sendo estudado por executivos de grandes empresas e especialistas em marketing, propaganda e administração de carreiras esportivas, bem como o gerenciamento de competições. A ascensão de uma economia do e no futebol é responsável pelo surgimento de um setor empresarial significativo, com dedicação extrema nesse ramo. No Brasil, a maior representante deste nicho é a empresa Traffic Sports. Formada por renomados profissionais do futebol - ex-técnicos, por exemplo - e por gestores com curso superior em Administração, Recursos Humanos e Economia, ela é responsável pela administração de carreira de aproximadamente 60 atletas do futebol, de acordo seu próprio portfólio. Além disso, possui uma ampla carteira de serviços dentro do esporte. De treinamentos específicos para potenciais agenciadores, "olheiros", técnicos e membros de comissões técnicas, a empresa possui setores específicos de ativação de projetos esportivos, gerenciamento de imagem, técnicas de $\operatorname{coach}^{2}$ e sua segunda maior atividade de arrecadação está na área de comercialização dos direitos internacionais de TV em competições latino-americanas, bem como a negociação dos

\footnotetext{
2 De técnica específica das grandes empresas na elaboração e atingimento de metas, sejam elas de produção ou mesmo venda, o coach também se voltou para o empreendedorismo pessoal. Ou empresariamento do indivíduo. Aquilo que Laval e Dardot (2013) demonstraram como um modus operandi tipicamente neoliberal. Chamados à liberdade, homens e mulheres são conclamados a se conceberem como empresas. Objetivo, sucesso e fracasso são mais que simples palavras e momentos para os indivíduos na sociedade capitalista pós-moderna.
} 
patrocínios e locais de exposição das marcas patrocinadoras nesses eventos. Esta é apenas uma das muitas facetas assumidas pelo empreendedorismo voltado ao esporte business. $\mathrm{O}$ futebol inglês, o primeiro a passar historicamente pela fase modernizadora, teve em meados do século XX uma primeira experiência que permitiu aos clubes de futebol a significativa transformação de simples agremiações esportivas em “companhias', convertendo-se de associações privadas em companhias limitadas" (BIRLEY apud GIULIANOTTI, 2002), assegurando fatias de ações no mercado financeiro a investidores e sócios proprietários. Giulianotti (1999) argumenta a possibilidade de ganhos com o clube, a partir de sua transformação em companhias limitadas, pelo fato do Código Comercial inglês (Companies $A c t$ ) ter facilitado a “regulamentação das sociedades” por quotas. Segundo o sociólogo

desde a década de 1960, a economia política do futebol passou por uma rápida modernização, uma vez que seus famosos jogadores e clubes foram incorporados mais profundamente na maior mercantilização da cultura popular.

Vale mencionar a diferença conjuntural entre a Inglaterra, analisada por Richard Giullianoti e os países sul americanos. Como este é um objeto volátil e metamórfico, as próprias pesquisas sobre o mundo futebolístico também incorrem nessa metamorfose, que se altera de localidade em localidade e vive em parâmetros comparativos muito complexos para serem simplificados. Uma "pelada” ao sul do país pode ter sentidos e significados completamente distintos do - a priori- mesmo rito que acontece no centro de São Paulo. Ainda que mantenham uma mesma estrutura aparente, embora até mesmo ela possa ser diferente, as conotações podem se apresentar diversamente. Isso ocorre em um mesmo território, que dirá em países e tempos históricos mais longínquos. Por isso, em se tratando de Brasil, para Alvito (2006), as décadas de 1960 até 1980 trazem consigo "forte controle estatal impedindo inovações, [tendo] calendários irracionais, federações controladas, campeonatos deficitários, violência nos estádios." Com o passar dos anos os clubes brasileiros fariam o caminho mercantilizado do futebol inglês, em uma outra escala, é verdade. Com nuances diferentes do processo ocorrido na Inglaterra, o Brasil seguiu uma legislação própria no tocante à estrutura econômica dos clubes de futebol. A lei no 9.981/2000 em seu artigo 27 facultou às entidades esportivas sua transformação em "sociedades civis de fins econômicos" ou 
“sociedades comerciais”. Contudo, manteve a proibição aos clubes já constituídos, de serem propriedades exclusivas de uma pessoa física e/ou jurídica, mantendo-se conforme a lei no 9.615/1998 - mais conhecida como "Lei Pelé" -, no artigo 16, como "pessoas jurídicas de direito privado, com organização e funcionamento autônomo", na sua maioria gerido por conselhos deliberativos, com cargos hierarquizados eleitos por sócios do clube. Ao contrário do exemplo inglês, em que um indivíduo-grupo tem a oportunidade de comprar um clube ou mesmo se tornar sócio majoritário ${ }^{3}$ das suas ações no mercado financeiro.

Ao surgimento e consolidação durante as décadas de 1980/90 dos setores voltados à administração esportiva soma-se a comunicação, setor que tem braços de análise de negócios muito alinhados aos planos de TV e marketing a fim de promover a tal incorporação ao capitalismo. Até 2013 os integrantes do "Clube dos 13" - clubes considerados a elite no futebol brasileiro - recebiam juntos da TV Globo, apenas pelos jogos a serem exibidos em suas afiliadas no "canal aberto" - excluindo o sistema de payper-view que também é parte dessa emissora -, 365 milhões de reais. Para 2016, o valor foi reajustado para 520 milhões $^{4}$. Um dos pontos que propiciaram o comércio do esporte foi a TV, a partir das transmissões dos jogos e o pagamento desse direito de transmissão aos clubes. Logo, o setor empresarial viu ali a possibilidade de utilizar os espaços (desde os espaços de jogo até os uniformes dos times) como seus outdoors, uma propaganda capaz de atingir milhares de espectadores e possíveis consumidores em potencial. $\mathrm{Na}$ Copa do Mundo da Alemanha, a décima sétima da história dessa competição, foi atingida uma audiência televisiva de mais de 3 bilhões de telespectadores, com uma receita em patrocínio que girou na casa de 18 bilhões de dólares (SÁNCHEZ, 2006). Enquanto isso o público total nos estádios das 12 cidadessede foi de 3.353.655 indivíduos (BAGGIO, 2013). A Copa do Mundo anterior, sediada por Japão e Coréia do Sul, já havia batido um grande recorde de telespectadores

\footnotetext{
${ }^{3}$ São conhecidas as histórias de Roman Abramovich, magnata russo, ligado a indústria do petróleo e dono do Chelsea F.C, bem como a família Agneli dona da Juventus de Turim e das indústrias automobilísticas e agrícolas - Fiat e New Holland - e também do ex-primeiro ministro e magnata italiano Silvio Berlusconi, dono do A.C Milan. Ambos os times após serem vendidos aos bilionários, colecionaram bons resultados nos campeonatos nacionais e ligas europeias. Graças aos investimentos pesados em jogadores, técnicos e toda uma estrutura física de centros de treinamentos a laboratórios voltados a medicina esportiva e estudo dos atletas.

${ }^{4}$ Os dados são de reportagens da emissora ESPN Brasil (01/10/2013) e do jornal Folha de São Paulo (29/09/2013) ambas do jornalista esportivo Paulo Vinícius Coelho.
} 
estimados em 1 bilhão em todo globo terrestre. Segundo dados posteriores da FIFA, ambos os países desembolsaram juntos 6 bilhões de dólares na realização do evento. Foram 20 estádios, um público total de 2.709.100 pessoas, com uma média de público de 42.330 torcedores nos estádios. A isso se soma o interesse de grandes empresas patrocinadoras, como a Coca-Cola, McDonalds e Gillette que desaguaram nos dois países entre 35 e 45 bilhões de dólares. A essas cifras juntem-se os outros 45 milhões da "moeda mundial" norte americana que a empresa de material esportivo, a alemã Adidas desembolsou. ${ }^{5}$

Com um produto tão promissor em relação às possibilidades de lucros exorbitantes, tanto os canais especializados em esporte têm aumentado consideravelmente na rede por assinatura, quanto o conglomerado empresarial tem voltado cada vez mais seus olhos e seu capital ao setor. Após a Copa do Mundo de 2014, um dos mais respeitados institutos brasileiros de pesquisa realizou consulta àqueles que de alguma forma apoiaram, financeiramente o evento por meio de patrocínios. A conclusão do IBOPE foi de que

\begin{abstract}
a Copa do Mundo trouxe bons resultados para as marcas que apostaram na FIFA e na CBF. (...) Apesar da derrota da seleção brasileira, as marcas envolvidas no evento esportivo tiveram uma grande exposição espontânea nas redes sociais, sempre associadas a sentimentos positivos. Em mais de 80 ações analisadas pelo instituto, pelo menos doze marcas tiveram taxas de conhecimento, interação e compra acima da média. As ações que trouxeram maior retorno foram lançamento de produtos temáticos, brindes para presentear o torcedor e desconto nos produtos (IBOPE-Inteligência).
\end{abstract}

Outro fator importante demonstrado no marketing esportivo na Copa de 2014 foi o tipo de mensagem exposto após a derrota da seleção brasileira para a Alemanha. $\mathrm{O}$ placar final, considerado trágico, 7x1 para os alemães, logo foi assimilado por muitas empresas que se ligaram ao evento. $\mathrm{O}$ discurso das propagandas, antes da eliminação, era sempre positivo, quanto a expectativa na classificação. Após a derrota passou a funcionar o discurso da superação. $\mathrm{Na}$ pesquisa acima citada, o instituto também mensurou como os torcedores-consumidores, que apostavam no sucesso da seleção

\footnotetext{
${ }^{5}$ Reportagem da Revista Veja de 05 de junho de 2002. Também em Botelho (2006).
} 
brasileira, avaliavam aquelas marcas a partir de três posturas, tidas como estratégicas pelas empresas. A saber:

*tirar o antigo comercial do ar;

*mantê-los;

*realizar novos comerciais de incentivo, superação e apoio.

Grande parte dos entrevistados demonstra alguma forma de apoio à seleção e insatisfação com as empresas que se abstiveram dessa postura positiva. A pesquisa demonstra, portanto, um desgaste na imagem dessas corporações e um significativo valor do discurso casado, aquele onde determinado produto se vincula a um evento para ver aumentado seu potencial de venda. Uma dimensão, diríamos, "industrial” de apropriação da cultura ligada aos produtos de mídia. Nela percebemos, então, uma lógica da produção capitalista no processo produtivo da informação em busca do convencimento. Comerciais publicitários nada mais são que o convencimento de uma necessidade, muita das vezes inexistente, amplificados pelo sentimentalismo de uma ação e momento. No caso acima, a paixão a uma seleção de futebol, que representa um país em um momento onde um grande evento era realizado em seu solo com toda carga emocional e de um sucesso promissor, esperado por grande parte da população.

Mídia, produtos e uma paixão nacional, o futebol. E nas Copas do Mundo de futebol ficam demonstradas todas as contradições entre o amor e o ódio a uma equipe e a um país, mas também grandes fatores vêm à tona, embora alguns ainda mencionem o esporte como uma forma de ópio. O próprio ato de comprar ou boicotar um produto é um ato político; já que "somos todos políticos 'ocasionais' quando votamos ou consumamos uma expressão de intenção semelhante, como aplaudir ou protestar" (WEBER, 1982).

\section{Uma paixão na TV}

As quantias das chamadas cotas de televisão vêm se tornando, ano após ano, mais volumosas e com isso mais importantes para a vida financeira de um clube de futebol, ao fazer com que, financeiramente, o torcedor não seja tão importante dentro do estádio para manter a "saúde" econômica do clube pelo qual torce. Em uma declaração 
polêmica, quando da reforma do seu estádio em Curitiba, um diretor do Clube Atlético Paranaense (CAP) mencionou não querer "aquele público que bebia, ficava bêbado e depois ia ver o jogo dentro do estádio". O que ele queria "um público mais espectador". Em outra ocasião, Mauro Petraglia, presidente do mesmo clube, afirmou que a Arena da Baixada foi reformada sem ajuda da torcida. "Todo o crescimento, toda a transformação havida nestes 20 anos no Furacão aconteceu sem nenhuma, absoluta e material, ajuda da torcida". "O nosso patrimônio vale hoje um bilhão de reais e foi construído sem um mísero tostão da torcida"6, o que causou polêmica e manifestação das torcidas organizadas do CAP.

A lógica atual é a de "menos é mais". Tanto que, nos últimos campeonatos nacionais constatou-se uma queda drástica de frequentadores de estádio, mesmo assim agremiações como o São Paulo Futebol Clube se utiliza de valores de ingressos mais caros para obter uma margem de lucro semelhante a de estádios mais cheios. $\mathrm{O}$ aumento de preço em 10 anos (2003-2013) frequentou a casa dos 300\%. Ultrapassou, consideravelmente, os $73 \%$ de inflação medidos pelo IBGE, através do IPCA (BARROS, 2013). Gaffney (2013) aponta um “crescimento da renda dos clubes”, em contraponto, estádios esvaziados. Isso porque, segundo ele há um processo de elitização ocorrendo nas principais praças de um esporte que ao longo de sua história se tornou o mais popular do mundo. Contudo, os clubes fazem a opção de preços mais altos e público mais selecionado nas partidas. Além de, por exemplo, ser impensável no futebol atual o gigantismo dos estádios dum passado recente. Aqueles que são construídos ou reformados têm, obrigatoriamente, sua dimensão reduzida.

A análise da tabela 1, quando mostra a arrecadação com bilheteria, no ano de 2015, do Clube Atlético Mineiro é impensável há tempos atrás. Mesmo disputando o título do Campeonato Brasileiro até as últimas rodadas, o clube preferiu mandar suas partidas na Arena Independência - com capacidade para pouco mais de 23.000 pessoas, do que no "Gigante da Pampulha”, ou Estádio Governador Magalhães Pinto, que, mesmo com a capacidade reduzida, após as reformas para a Copa do Mundo de 2014, possui uma capacidade de 62.000 lugares. O clube privou boa parte dos seus torcedores de acompanhar sua campanha e um dos argumentos foi a falta de acordo com a

\footnotetext{
${ }^{6} \mathrm{http}: / /$ www.gazetadopovo.com.br/esportes/futebol/atletico-pr/petraglia-diz-que-patrimonio-do-atleticofoi-construido-sem-um-misero-tostao-da-torcida-ej1bw73akh5u5ahkrut68rwib Acesso em 25/07/2015.
} 
administradora do estádio e com o Cruzeiro Esporte Clube, mas fragrante é a relação entre capacidade espacial - aumento do valor de ingresso.

Toda essa diminuição de público nos estádios também se deve ao fenômeno da televisão. A tabela 1 mostra juntamente o ganho bruto, com público, que os 2 clubes mais bem colocados nos últimos 3 campeonatos nacionais (2013, 2014 e 2015) obtiveram nos jogos em que foram mandantes e a confrontação com os direitos de imagem (cotas de televisão) pagos ao clube no mesmo ano.

Tabela 1 - Renda do campeão e vice (Bilheteria / Cota de TV)

\begin{tabular}{|c|c|c|c|c|c|c|c|c|c|}
\hline & 2013 & & & 2014 & & & 2015 & & \\
\hline Colocação & & $\begin{array}{l}\text { Ganho com } \\
\text { público* }\end{array}$ & $\begin{array}{l}\text { Cota de } \\
\text { televisão** }\end{array}$ & & $\begin{array}{l}\text { Ganho com } \\
\text { público* }\end{array}$ & $\begin{array}{l}\text { Cota de } \\
\text { televisão** }\end{array}$ & & $\begin{array}{l}\text { Ganho com } \\
\text { público** }\end{array}$ & $\begin{array}{l}\text { Cota de } \\
\text { televisão** }\end{array}$ \\
\hline $1^{\circ}$ & Cruzeiro & 27.524 .479 & $45 \mathrm{mil}$ & Cruzeiro & 27.585 .105 & $45 \mathrm{mil}$ & Corinthians & $38.740 .817,45$ & $110 \mathrm{mil}$ \\
\hline $2^{0}$ & Grêmio & 14.438 .797 & $45 \mathrm{mil}$ & São Paulo & 14.098 .081 & $80 \mathrm{mil}$ & Atlético - MG & $16.225 .490,50$ & $45 \mathrm{mil}$ \\
\hline
\end{tabular}

*Jogos como mandante no Campeonato Brasileiro. Renda bruta.

**Valores em milhões $(\mathrm{R} \$)$

Como é um pacote no formato de um produto, o futebol televisionado precisa passar por uma formatação a fim de ser comercializado sem as "sujeiras" aparentes. Tudo o que pode atrapalhar a transmissão da imagem deve ser retirado a fim de proporcionar os espaços necessários para a colocação de placas, banners e todo um conjunto de símbolos como as "marcas d’água”, por exemplo. Ou mesmo o aparecimento das logomarcas dos patrocinadores. A mesma tabela citada anteriormente demonstra os valores pagos pela emissora de TV que controla as transmissões de grande parte das competições futebolísticas brasileiras. Além de detentora desses direitos na chamada “TV aberta", possui mais três canais esportivos na "TV por assinatura", além do sistema pay-per-view. Na Copa do Mundo de 2014, um dos canais, o SporTV - na TV fechada , da emissora superou seus concorrentes nas trinta e duas partidas transmitidas. Possuindo uma audiência de 77\% na soma dos outros canais concorrentes e o dobro do segundo colocado, a franquia ESPN. Um grande monopólio do direito de imagem dos clubes realizado mediante contratos com as próprias agremiações, além de federações estaduais e do contrato exclusivo com a Confederação Brasileira de Futebol (CBF) para transmissões nacionais e internacionais de jogos da seleção brasileira. Com isso, os interesses financeiros dos clubes, passam, logicamente adiante dos interesses dos torcedores. 
Com a crescente tendência dos chamados patrocínios másters, os campeonatos passaram a ter o nome de uma empresa em si. No campeonato carioca de 2015, a Viton44 - empresa brasileira do ramo alimentício, detentora dos produtos de bebida como o Guaraviton, Guaravita e Matte Viton -, tem dominado as camisas dos times cariocas. Só a dupla Fla-Flu embolsou deste patrocinador $\mathrm{R} \$ 34$ milhões pelo patrocínio na respectiva temporada. Como citado, período de grande crescimento da entrada de empresas no ramo do futebol, os anos 1990 também marcaram uma conturbada relação dos torcedores. Podemos identificar essa década como um período inicial de uma transição que ocorreria subsequentemente: a do torcedor em consumidor.

Nas placas de marketing centrais dos estádios não se vê mais apenas escrito o nome do campeonato em questão. O "Campeonato Brasileiro" de 2014 tornou-se o "Brasileirão Chevrolet 2014". O "Campeonato Carioca" de 2015 recebeu o nome de "Cariocão Guaraviton" e a competição mais almejada em toda a América do Sul a "Taça Libertadores da América", uma homenagem aos "heróis" nacionais de cada país sulamericano recebeu em 2015 o nome de "Copa Bridsgestone Libertadores", pois é apoiada financeiramente por uma empresa de pneus automotivos.

\section{Torcer entre sol, suor e cerveja}

Tamanha influência do grande capital nos eventos esportivos foi visto durante a Copa do Mundo de 2014. Tendo sido proibida em 2003 pela lei federal nos estádios brasileiros e arredores, o consumo de cerveja foi liberado nas dependências internas graças ao interesse do conglomerado belgo-brasileiro Anheuser-Busch InBev, dono de grande parte das marcas comercializadas em território nacional - inclusive a Budweiser, originalmente estadunidense, recém adquirida pelo grupo cervejeiro. A proibição existente com base na legislação brasileira constante tanto de normas da CBF, Estatuto do Torcedor, leis estaduais e até mesmo de um Termo de Ajustamento de Conduta (TAC) foi suspensa para o megaevento de 2014.

O texto da respectiva lei rezava em seu Capítulo IV, artigo 13-A:

São condições de acesso e permanência do torcedor no recinto esportivo, sem prejuízo de outras condições previstas em lei II - não 
portar objetos, bebidas ou substâncias proibidas ou suscetíveis de gerar ou possibilitar a prática de atos de violência.

No acordo (TAC) firmado entre CBF, Polícia Militar e Ministério Público ficara acertada a proibição nos seguintes termos:

1) É proibida a venda e o consumo de bebidas alcoólicas no interior dos estádios, em todas suas dependências, durante dias de jogos de competições organizadas pela FCF;

2) $\mathrm{O}$ descumprimento das obrigações gera multa de $\mathrm{R} \$ 1$ mil por infração cometida.

Ao retornar aos estádios em 2014, a brecha para a autorização definitiva estava aberta. No estado do Rio de Janeiro, foi sancionada em 2015 a venda através do projeto de lei 799/15 dos deputados estaduais Luiz Martins (PDT), Geraldo Pudim (PR) e Wanderson Nogueira (PSB). Com determinadas restrições, caso da proibição de latas de alumínio ou garrafas de qualquer natureza. A cerveja - única bebida alcóolica disponível nos recintos - só pode ser comercializada em copos plásticos ou de papelão e nas cantinas e lanchonetes dos estádios. Justificando o texto do projeto de lei, os deputados argumentavam não ter havido casos consideráveis de violência no evento anterior Copa do Mundo - onde, como exposto acima, se deu o start para o retorno da bebida aos estádios. Contudo, o que ficou de fora da observância de ambos os membros do Legislativo foi a clientela que, por ocasião, frequentou aquele evento e o público típico dos estádios de futebol. Também a rivalidade entre as seleções ser bem mais contornadas e controláveis que entre times. Em nossas pesquisas de campo, nos deparamos com ambos personagens ou tipos de torcedores, já que todos, de alguma forma, possuem um determinado vínculo com o esporte no sentido de dar vivência e significado a um sentimento.

O tema violência é assunto já bem tratado no universo do futebol. Inúmeros estudos são considerados de excelência ao tratar esse aspecto torcedor, principalmente na construção das torcidas jovens e associações ao ethos violento de grupos de torcedores, principalmente as chamadas torcidas organizadas ou uniformizadas. Nas ciências humanas e sociais, há os estudiosos que se baseiam na tese de que o esporte, o futebol em si, é um ato simbólico da violência contida dos diferentes grupos humanos; ou melhor, 
convive com esses atos em seus modus; uma "violência simbólica" encerrada em uma "guerra simbólica" - o jogo em si. Galeano (2012) descreve o futebol como

sublimação ritual da guerra, onze homens de calção acabam sendo a espada vingadora do bairro, da cidade ou da nação. Estes guerreiros sem armas nem couraças exorcizam os demônios da multidão (...) em cada confronto entre duas equipes entram em combate velhos ódios e amores herdados de pai para filho.

Murad (2007) considera tênue a linha que divide o simbólico da manifestação física que se concretizaria no ato violento. $\mathrm{Na}$ linguagem do escritor uruguaio, há um forte linguajar dos termos militares; embora de um modo escrito em que paira uma brisa romântica. Para aquele sociólogo, autor de vários livros sobre a violência no futebol, a

manifestação [do ato violento] ficaria a depender, tão somente, de algum estímulo externo: anomia, impunidade, descaso das autoridades, conexão com outros níveis de agressividade direta (...) ou indireta (...).

$\mathrm{Na}$ agressividade direta entrariam questões como as drogas - bebidas alcóolicas, por exemplo -, mas também o racismo e outras formas de preconceito, os quais se manifestam muito rotineiramente à beira dos gramados e parecem já fazer parte da cultura do jogo. Quem vai ao estádio pela primeira vez pode estranhar o comportamento de alguns torcedores. Agressões verbais feitas mediante xingamentos aos adversários sejam eles dirigidos ao time ou ao próprio torcedor -, ridicularizações das mais variadas, que vão da acentuação da forma física ou de algum item da vida pessoal de jogadores do outro time a vaias.

Nos anos iniciais do século XXI, começam a surgir vários movimentos de torcedores organizados que buscam, por suas ações, comportamentos de torcer e mesmo a forma como encaram o futebol se distinguir das torcidas jovens tradicionais. Geralmente não possuem em seu nome a palavra "organizada" ou mesmo "torcida”, procuram nomes como "movimento" para se identificarem. Entretanto, uma das entrevistadas possui a alcunha Barra. Justifica o uso - como veremos na entrevista - por influência das torcidas argentinas, uruguaias, chilenas... as Barra bravas. Seus 
posicionamentos na prática em muito se assemelham à carnavalização ${ }^{7}$ do espetáculo do torcer, entretanto, dentre esses grupos, muitos são os que não incentivam a "velha forma" de torcer. O modus operandi está em incentivar o time nos 90 minutos da partida, sem críticas ofensivas, vaias ou comportamentos similares. Ocupam espaços determinados no estádio do Maracanã. Aqueles que destoam dessa forma de torcer são, inclusive, repreendidos pela maioria do grupo, ou por aqueles que estão próximo no momento do jogo. Realizando um trabalho de campo sócio etnográfico, numa espécie de "estar lá" (GEERTZ, 2009) ${ }^{8}$, me instalei entre os torcedores desse "tipo de torcida" (referência dada por um torcedor "tradicional", membro de uma torcida organizada) a fim de observar a maior parte do tempo seus comportamentos e perfis. Após alguns contatos, realizei entrevistas. E algumas constatações foram interessantes. Diferente das torcidas tradicionais, nesse "movimento torcedor" - assim identificado por um torcedor - não há uma hierarquia rígida, com presidente, tesoureiro etc. Nem mesmo cadastro de membros. As relações são depositadas na reciprocidade das ações. Todos podem ajudar tendo uma organização de tarefas específicas, geralmente por jogo. A responsabilidade varia com a disponibilidade no cumprimento do que foi decidido entre os membros. Fica nítido que há determinadas lideranças, mas não aparecia uma estrutura de poder, como por exemplo das torcidas organizadas. Intituladas como "velhas" por dois entrevistados, embora o poder possa estar "onde ele se deixa ver menos" (BOURDIEU, 1989).

Outro dado captado é o fato de a maioria dos membros estar na faixa entre 16 e 25 anos - embora haja membros nascidos nas décadas de 1970 e 1980 - cursarem o Ensino Médio ou Graduação e já possuírem uma rede de convivência anterior à existência do movimento torcedor. Também não viram ou torceram na antiga estrutura física que o Maracanã possuía. Isso, talvez, também ajude a configurar essa nova forma de torcer, pois muitos dos entrevistados se diziam "contra o futebol moderno". A justificativa apresentada por um dos membros - responsável conjuntamente com outras duas pessoas pelas informações nos grupos da web - para a criação do movimento se baseia na contrapartida ao velho modelo do torcer.

\footnotetext{
${ }^{7}$ Termo muito usado pelos estudiosos do futebol - Buarque de Hollanda (2010), Teixeira (2003), por exemplo - para descrever a festa dos torcedores nas arquibancadas. Seu início se dá com Mário Filho. O assunto será tratado no segundo capítulo.

${ }^{8}$ De todo o debate na antropologia social o "estar lá" de Geertz, coloca a questão, justamente da presença do etnógrafo onde as pessoas "vivem e estão", de maneira prática.
} 
A gente via as torcidas sul americanas (barra bravas) e se inspirava neles. O tempo todo cantando. O Boca [Juniors - time argentino] perdendo e a torcida atrás do gol enlouquecida, cantando muito. Aí pensamos. Vamos fazer igual. Nasceu nosso movimento. É diferente de todas e às vezes isso incomoda. Por que como eles têm acesso aos jogadores, ao clube, dirigentes eles ganham determinadas coisas que nós não. Como ingressos, por exemplo, festas... Aí eles tem que aplaudir um jogador que está mal. Nessa hora a gente incentiva também. Mas sem ganhar nada em troca.

Não só homens fazem parte do movimento torcedor, as mulheres têm papel importante e incentivam efusivamente o time durante a partida. Larissa Franca, 21 anos, está no $3^{\circ}$ ano do Ensino Médio, é moradora do Méier e "doente pelo seu time de coração".

Num primeiro momento em um diálogo aberto - no sentido metodológico, o questionário seria aplicado em outro momento -, Larissa falou sobre o velho e novo o modus do torcer.

\begin{abstract}
Nós torcemos diferente. Você viu. A gente não xinga direto. Não vaia. E se o time está perdendo a gente apoia mais. Temos um lema: "nas boas eu te apoio. Nas más eu te amo.” É o que a gente faz o tempo todo. Temos isso. Somos diferentes por causa disso. A (outra torcida) vai xingar, chamar os jogadores de (...) mas nós não. Às vezes sai, não é! Fico "puta" com jogador, com técnico, até com a torcida. Mas o principal é se manter ativo. Pulando, gritando, balançando nossas bandeirinhas. A (outra torcida) é grande é umas das primeiras [do time]. Eles têm grana. A antiga [patrocinadora] dava dinheiro, churrasco, viagem, caravana, material. Tudo! Nós fazemos o nosso com pouca grana. Aqui não tem sócio. Você vem e torce. Não paga nada se quiser ir no churrasco. Só a carne e a "birita". Mas não tem essa de sociedade. A gente vende nosso chapéu, camisa e só. É na raça, no gás. Tem que fazer material. Coloca a mão no bolso aí, parceiro. "Tu tem" quanto? $\mathrm{R} \$ 10$ ? Passa pra cá. Que a gente tem que comprar pano. É assim.
\end{abstract}

Temas que constam nas agendas sociais de movimentos sociais também estão presentes em muitos desses movimentos torcedores. Como muitos são estudantes, o debate é tanto mais compreensivo e apropriado, pois também são temas vistos no dia a dia das salas de aula. Torcidas femininas que buscam a afirmação do espaço feminino nos estádios, também torcidas de apoio à causa $L G B T S$ com uma grande reivindicação da igualdade de gênero. Larissa também mencionou esse ponto em sua entrevista 
mostrando-se articulada com determinado pensamento. Segundo ela, é uma preocupação desses novos movimentos jovens, em que a provocação ao outro dá lugar ao apoio incondicional ao time. "Nossa preocupação é o [time], o adversário é problema do jogador e da torcida deles." Em determinado momento interrompi sua fala para questionar se era questão de ser politicamente correto.

\begin{abstract}
O futebol não é coisa de macho. Não aqui [na torcida]. É coisa de gente. Não importa o sexo. E por isso que uma das coisas que a gente faz é não fazer piadinha de homossexual. Do tipo, tal jogador é "viadinho". Ou esse time é de "bambi". Tem homossexual em todas as torcidas. Tem homem, mulher, padre, ladrão. Vou ficar ofendendo o cara porque ele gosta de outra coisa? Aqui a gente se preocupa. Temos amigos que são. E daí? A paixão deles é a mesma da minha. Falo da CBF e faço a mesma coisa? Aqui é diferente. Até esse "lance" de chamar flamenguista de favelado é ruim. $\mathrm{Na}$ favela tem botafoguense, tricolor, vascaíno, rubro-negro. Tem tudo. Sabia que tem polícia que mora na favela? Meu tio é tricolor e mora na Rocinha. Aí eu canto que a favela tá em silêncio por causa do Flamengo. Então a gente é assim. Mas não é que é de todo correto. Todo mundo fala desse negócio de politicamente certinho. Mas pensa no cara que é chamado de bicha? Já pensou? O cara tem sentimento. Se ofende. Aí, o cara tem time e pode ser igual ao seu. E aî? O quê que "tú" vai dizer pra ele? Não torce não por que aqui é time de machão. "Pô" maior conversa atrasada. Quem pensa assim é meu avô, nem meu pai. Isso é do "tempo que Don Don jogava no Andaraí."
\end{abstract}

Uma coisa corre o risco de passar despercebida na fala de Larissa. É ela a apropriação. Tão comum entre as torcidas. Por exemplo, a torcida do Flamengo se apropriou da paródia feita com a música "Poeira" de Ivete Sangalo. Transforma o "silêncio na favela" cantada pelas torcidas adversárias quando o rubro-negro está em desvantagem no placar, para "festa na favela" quando a situação é justamente a contrária. $\mathrm{Na}$ nota acima sobre o texto de Maurício Pinto (2014), ficam evidentes os exemplos de apropriações e ressignificações realizadas pela "comunidade livre" do São Paulo F.C. Chamados depreciativamente pelos adversários de "Bambi" - menção ao filme produzido pela Walt Disney, adaptação do livro Bambi. Life in the woods (Félix Salten), no qual o personagem principal é um veado -, a "torcida" queer são-paulina se apropriou da alcunha e deu novo significado a ela. Assim como a Gaivotas da Fiel, uma espécie de paródia com a Gavióes da Fiel, principal torcida do Sport Club Corinthians Paulista e uma das maiores do Brasil. 
$\mathrm{Na}$ tal cultura do jogo, associada a uma dentre várias formas da cultura do torcer, está inserido, inclusive, o consumo de álcool antes, durante e após as partidas. É comum a reunião de grupos em bares e afins antes de se dirigir aos estádios ou mesmo permanecer para torcer juntos naquele ambiente. Gastaldo (2005) sinaliza a sociabilidade nesses espaços, em dias de jogos, como forma de uma interação com aproximações ao torcer nos estádios - cantos, xingamentos, confrontação, por exemplo. Traçando também diferenças, o espaço é levado em consideração, a observação etnográfica do autor verifica o comportamento do público masculino e as representações feitas ali. Em contato com membros de uma torcida organizada no interior do estado do Rio de Janeiro, a partida ocorreu no Estádio da Cidadania, em Volta Redonda, pudemos constatar a importância do rito do encontro. $\mathrm{O}$ entrevistado, disse que

\footnotetext{
sempre que o Flamengo joga aqui a gente se encontra nesse 'botequim'. Toma umas [cervejas] e vai a pé. Aqui é casa, já é?! O dono, aí, já conhece quando a gente chega. Tudo de boa, na paz. Mas tem que tomar umas. Sorte não dá. Quem acredita em sorte é botafoguense. O GEPE (Grupamento Especial de Policiamento em Estádios da Polícia Militar do Rio de Janeiro) só guia o ônibus até o Raulino [Estádio Raulino de Oliveira ou Estádio da Cidadania], a gente salta e vem pra cá. Depois voltamos [ao estádio]. Aqui se reúne a galera da Baixada [Fluminense] também e o pessoal daqui [Sul Fluminense], aí é só beber e fazer a festa.
}

Questionado sobre a questão da violência e associação com as bebidas, o mesmo se colou à favor da venda nos estádios, justificando que "não é a bebida que traz a violência, mas a falta de respeito e a polícia”. Embora tenha ponderado que a utilização pode potencializar as ocorrências agressivas entre torcedores rivais e até mesmo entre membros de uma mesma torcida/time, o torcedor cita, por exemplo, o caso da comemoração do campeonato brasileiro de 2009 pelo Flamengo em que viu uma briga entre membros de torcidas rubro-negras.

Quem quer brigar, vem pensando nisso desde casa. A gente bebe e não briga. Mas pode acontecer. Eu já briguei muito, de cara limpa e bêbado. Hoje 'to' de boa. Sem confusão. Sou da turma do "deixa disso". [Nesse momento, um outro membro da mesma torcida que estava próximo a nós se vira e entra na entrevista] "é mas já quase matou uns três de porrada! Nosso entrevistado principal se justifica. Pô, outra época, pode crer?! Mas hoje eu separo. Claro que não vou 
deixar "alemão" encostar em parceiro meu. Mas se der pra separar, melhor. Tranquilo.

Quando o "Mengão" ganhou o brasileiro. Lembra ?[falando com outro torcedor]

Lá no "Burburinho" rolou pancadaria entre a gente e os caras. Chegaram botando marra e a gente já tava lá comemorando.

Entretanto, dentro dos estádios os dados são imprecisos dessa associação, visto que somente nessa temporada de 2016 o hábito entrou em vigor entre os torcedores, nos estádios cariocas.

Já a agressividade direta teria relações mais insufladas pelo campo do sócio econômico. Os problemas sociais enfrentados pela sociedade e consequentemente pelos jovens em início de carreira que, com o desemprego, passariam a se utilizar de um ócio de desconstrução tanto no tempo livre quanto nos espaços de entretenimento, como os pubs e logicamente os estádios de futebol. Essa interpretação, que associa, por exemplo, o desemprego ao aumento de violência nos estádios é muito corrente na sociologia e antropologia do esporte na Inglaterra. Justificada muito pelo fato do combate ao hooliganism ter sido realizado em pleno neoliberalismo inglês, no governo de Margaret Thatcher (1979-1990) numa crise econômica inglesa. O álcool também foi abolido como forma de prevenir a violência no interior dos estádios. Com todo o debate sobre a questão da violência nos estádios e a potencialização ou não das atitudes violentas pela utilização do álcool, a Budweiser continuará a ser a bebida dos estádios nas próximas Copas. Com um patrocínio anual que beira os US\$25 milhões a parceria com a FIFA, foi renovada até o ano de 2022.

Sendo, portanto, uma mercadoria, o futebol sofreu e ainda vem sofrendo as grandes transformações para ser valorizado e vendido como um produto a ser exportado, importado e consumido em diferentes locais do globo terrestre. Como toda mercadoria tem seu valor de uso e de troca, sua capacidade e potencial para se transformar além das estratégias táticas de campo tem se mostrado irrefutável. Uma dessas transformações se dá no âmbito do lócus do jogo, o espaço onde mais se exalta - embora não unicamente a "paixão incontrolável do torcedor" (Alvito, 2006), o estádio de futebol. 


\section{O lócus e a empresa capitalista. O estádio, a cidade}

Gaffney (2010), ao observar a relação dos megaeventos com a dinâmica sócio espacial, demonstra a forma que denomina de "geografia olímpica". Ela tem seus próprios códigos, normas e leis e isso faz suspender, na maioria das vezes, a própria legislação do país e os direitos dos indivíduos em relação a um local ou mesmo um serviço prestado em um determinado espaço. Por ocasião das preparações para a Copa do Mundo de 2014, fez-se valer o previsto no artigo 11 do capítulo II da Lei Geral da Copa ${ }^{9}$. Como anunciara Gaffney, o dispositivo assegurava à Federação a delimitação das vias de acesso em torno dos estádios onde se dariam os jogos, não sendo permitida a circulação por parte de quem não estivesse com ingressos, a exclusividade na indicação de quem poderia vender quaisquer tipos de produtos, inclusive os do gênero alimentício nos arredores dos estádios. Tudo isso a fim de garantir uma espécie de monopólio comercial aos patrocinadores oficiais do evento. Logo, os comerciantes locais ficaram notadamente prejudicados.

O caso mais emblemático foi o do acarajé de Salvador, vendido pelas "baianas" no entorno da Fonte Nova, estádio soteropolitano escolhido para os jogos. Após uma longa pressão dos movimentos sociais e da comunidade local, além da exposição massiva em determinados setores da mídia, foi dada uma concessão mediante o cadastro das profissionais. Contudo, também foi estipulado um limite espacial para o posicionamento das barracas, a fim de evitar concorrência com os patrocinadores do evento. Por ocasião dos eventos-teste para as Olimpíadas de 2016, algumas situações em determinados locais da cidade do Rio de Janeiro já começaram a ocorrer. Entretanto, a prefeitura e a organização do evento alegaram que os direitos de ir e vir dos moradores seriam garantidos.

A suspensão das leis vigentes em um determinado território passa, em muitos casos, pelo fato de se garantir uma determinada mobilidade urbana, em locais onde essa é comprometida, por vários motivos, seja pelo trânsito de automóveis ou por um

\footnotetext{
${ }^{9}$ Aprovada em 5 de junho de 2012, a Lei no 12.663, previu a regulação não só da Copa do Mundo FIFA de Futebol (2014), mas também a Copa das Confederações e a Jornada Mundial da Juventude, ambas as últimas realizadas em 2013.
} 
planejamento arquitetônico na cidade que não propicie o fluxo desejável no escoamento dos indivíduos.

De acordo com a já citada Lei Geral da Copa em seu Capítulo VI - Das condições de acesso e permanência nos locais oficiais de competição, seu artigo 28 versava, dentre outros tópicos, a oficialidade de um determinado espaço público, bem como a autorização, ou não, de se fazer presente no mesmo. Para isso, era preciso estar na posse de ingresso ou documento de credenciamento, devidamente emitido pela Fifa ou pessoa ou entidade por ela indicada. Caso não fosse possível se enquadrar nesse tópico, o indivíduo estaria impossibilitado de permanecer em qualquer localidade demarcada como oficial. Na cidade do Rio de Janeiro, a demarcação territorial aconteceu a um raio de um (1) quilômetro do Estádio Mario Filho. Nesse espaço, parte do comércio foi comprometido, bebidas alcoólicas não podiam ser comercializadas, alguns moradores receberam credenciais de acesso, mas outros não, o que causou certo constrangimento durante alguns jogos.

Desde a década de 1960, o futebol faz parte de uma lógica mais acirrada de negócios, podemos observar que no presente ele já se consolidou como um business importante, não só para a economia esportiva; mas também para países e cidades que pretendem atrair grandes eventos, tais como a Copa do Mundo de futebol, para iniciar um novo processo de "avivamento" da cidade. O esporte é, portanto, um fator a contribuir para o refazimento dos espaços urbanos e consequentemente para vida dos citadinos.

Sendo tanto o estádio de futebol quanto as cidades locais onde a configuração e a reconfiguração física estão presentes, elas podem ter influências nas relações sociais de sociação. Como forma de sociação, a sociabilidade dos indivíduos nas arquibancadas pode sofrer influência direta do espaço modificado. Daí uma nova forma de sociação pode ser observada, com um menor nível de articulação entre aqueles ocupantes dos lugares no estádio. É perceptível que o modus vivendi de 30 anos atrás já não é mesmo dos indivíduos do tempo presente. A cidade já não é mais a mesma. Seus espaços foram alterados e os espaços dentro desses espaços também sofreram importantes modificações.

Simmel (1983) entende a sociedade como resultado de uma interação entre os indivíduos. Essa vivência que irá, consequentemente, gerar os conflitos, aproximações, interesses mútuos, enfim, formas diversas de viver e pensar a e na cidade. A sociação é 
justamente a relação de conflitos, aproximações que fazem os indivíduos no espaçotempo das cidades. Os espaços da cidade bem como todo seu movimento influenciarão esses indivíduos a viver no ritmo que a cidade proporciona. Lento, calmo, agitado, o espírito das cidades é completamente variável.

Lousada (1995) também entende a sociabilidade como "formas de convívio e de interação exteriores aos quadros elementares e de alguma forma compulsórios da vida social e coletiva”. Nos estádios, essa forma parece estar presente, justamente por estar fora desses "quadros compulsórios". Experimenta-se nesse espaço a suspensão do tempo, em certa medida. Mesmo existindo um relógio correndo em dois blocos de 45 minutos, o cronus parece estar fora do verdadeiro tempo da vivência, da experimentação do jogo, embora, dentro dos estádios, como em qualquer outro lugar, a experiência do cotidiano esteja presente. A experimentação do espetáculo futebol não anula por completo as sensações daquilo que se viveu fora daquele espaço geográfico. Ele pode inclusive, ser um local de enfrentamento dessa realidade dura, a qual nos deparamos nos espaços de vivência: a casa, o trabalho, os compromissos diários. O estádio, portanto, mesmo em suas novas configurações, alimenta o pertencimento e as identidades coletivas (GAFFNEY apud JESUS, 2014).

Velho Barreto ao citar Holanda (2011), parece concordar com este em sua afirmação de que o habitus do torcedor

\footnotetext{
é composto pela chamada via espacial - padrões de utilização do espaço edificado do estádio (...) sua utilização é (...) condicionada pelas possibilidades impostas pelas variáveis dos padrões espaciais, próprios da arquitetura de cada edificação.
}

Logo, os espaços podem ter influência direta no modus operandi dos torcedores. Portanto, "torcer" sendo obrigado a permanecer sentado em cadeiras numeradas ou em locais onde o "estar em pé" é possível, trariam significativas diferenças nesse modus torcedor, nas relações de interatividade, tanto uns com os outros como também na forma de interação com o que é visto no espaço do campo. Outrora, os grandes estádios brasileiros possuíam espaços populares como a "Geral" do Maracanã. Espaços geralmente baratos, quase caricaturais, com uma cultura e hábitos próprios. Impensável seria um "geraldino" torcer como "geraldino" nos espaços dos "arquibaldos". A "Geral" era um espaço que propiciava uma sociabilidade até mesmo do enfrentamento, de uma 
determinada solidariedade, do conflito como expõe Simmel, quando a convivência está encerrada em um espaço onde a liberdade de ser o que quiser é garantida por uma espécie de contrato livre entre os que ali frequentam. Da mesma forma, quando encerrados em um determinado espaço onde esse contrato exige determinadas posturas que aparentam liberdade a sociabilidade entre os indivíduos, acontecem de modo muito diferente do primeiro.

Um bom exemplo disso é demonstrado por Jesus (2014). Quando o Grêmio Foot-ball Porto Alegrense construiu seu estádio, a princípio as torcidas organizadas perderiam seu espaço de comemoração. Uma comemoração típica, muito influenciada pelas hinchadas ${ }^{10}$ argentinas, na qual após um gol, os torcedores correm até a grade que separa o campo, fazendo assim uma onda humana. Após muita pressão dos torcedores, a direção do clube reservou somente uma parte das arquibancadas para essa manifestação. Jesus afirma que a reserva desse espaço também consiste em uma forma de autoritarismo para com uma parcela dos torcedores. E essa reorganização do espaço, como nos casos acima, passam pelas reformas e modernizações. $\mathrm{O}$ motor das reformas não parece ter sido o controle das massas desordenadas, mas a nova economia do futebol (pós-1980) definia os contratos empresariais como a forma de arrecadação dos clubes em detrimento do público, assim defende Jesus (2014).

O geógrafo David Harvey traz em suas interpretações do espaço, a partir da teoria marxista, o entendimento de como os espaços das cidades sofrem grandes transformações estruturais baseadas e fundadas no interesse do capital. Desde o empresariamento nos espaços urbanos até as primeiras indagações de Marx à teoria de Hegel sobre o capital e a lógica das cidades, Harvey situa sua argumentação nas relações entre sociedade e espaço na economia capitalista. Como o capitalismo vive tempos de estagnação e crises,a pergunta de Marx para uma saída está em consonância com a formulação de Hegel que "deixada em aberto" diz respeito sobre como o capitalismo poderá se estabilizar pelo papel da expansão e dominação territorial. Passado o megaevento de 2014 o que temos observado são obras ainda em andamento, uma crise política e econômica que se arrasta e o grande capital financeiro representando pela FIFA e também pelas grandes empresas "parceiras" do evento, seguindo seus caminhos lucrativos rumo à próxima Copa do Mundo. O rearranjo espacial tende a se dar, não

\footnotetext{
${ }^{10}$ Como são chamadas as torcidas organizadas na Argentina e Uruguai.
} 
somente na cidade onde o evento acontece, mas ele é internacionalizado nos ganhos desses conglomerados. Seu capital cresce voluptuosamente, graças a oportunidade que a eles foi dada em fazer o megaevento num determinado território nacional.

Para realização de investimentos na cidade, a tendência no capitalismo tardio está justaposta como forma de parcerias entre o poder público e o poder privado a fim de promover a construção de áreas e locais de atração de novos investimentos. A exemplo da teoria, quando houve a última reforma no estádio do Maracanã (2013), uma das cogitações do consórcio vencedor da licitação pública foi a de construir, em anexo ao estádio, um Shopping Center, um aglomerado de lojas de conveniência, além de um estacionamento privado. Para isso, seria necessário pôr abaixo um museu e uma escola, um parque aquático e um centro esportivo, todos públicos.

Após uma grande movimentação pública, com grande participação de movimentos sociais, um novo contrato foi firmado entre poder público e o consórcio administrador, liderado pela empresa de construção civil Odebrecht, e , então, as demolições foram canceladas. Posteriormente, a prefeitura da cidade do Rio de Janeiro decretou em definitivo o tombamento tanto do Museu do Índio quanto da Escola Arthur Friedenreich.

Coloca-se, no entanto, que os modelos dessa parceria "público-privado" são especulativos na construção de um projeto. Nele, o setor público tende a ficar com os riscos e o poder privado com os lucros. As reformas do estádio do Maracanã ficaram a cargo de um consórcio que contou com duas das principais construtoras do país. Andrade Gutierrez e Odebrecht venceram a licitação que lhes garantiu, por meio da Lei 8.666/93 (Lei de Licitações), a realização de obra pública. O primeiro levantamento de custos estimados foi de 430 milhões de reais (em junho de 2009); já em abril de 2013, o valor tinha sido elevado para 808,9 milhões de reais; ao final, já tinha ultrapassado a casa de 1 bilhão de reais. Se antes, o Maracanã foi conhecido como "o maior do mundo", por ora, se tornou "o mais caro do Brasil". Sua reforma ultrapassou em valores a reforma do Estádio Mané Garrincha no Distrito Federal e também a construção do Juventus Stadium (Juventus da Itália). Este erguido do nada custou aos cofres do clube 100 milhões de euros, em 2011 quando foi inaugurado, algo em torno de R\$400 milhões de reais, levando em consideração a cotação da época das moedas. O valor financiado pelo BNDES (Banco Nacional de Desenvolvimento Econômico e Social) foi de 400 milhões de reais - excluídos os $\mathrm{R} \$ 304$ milhões advindos dos cofres públicos para a adequação do 
estádio nos Jogos Pan-americanos de 2007. Ao final, o consórcio vencedor da licitação para administrar o estádio ofereceu $\mathrm{R} \$ 181,5$ milhões divididos em trinta e cinco parcelas de $\mathrm{R} \$ 5,5$ milhões, em contrapartida administraria por 35 anos o complexo esportivo. No decorrer do Campeonato Brasileiro de Futebol do ano de 2016, o consórcio vencedor decidiu abandonar a administração do Estádio do Maracanã, por não haver obtido os lucros estimados. Criou-se dessa maneira um imbróglio para os clubes que se utilizavam do aparelho. Sem ter quem administrasse o estádio - o poder público também não demonstrou interesse em retomá-lo para si - os jogos foram redirecionados para estádios do interior do estado do Rio e mesmo para outras unidades da federação.

\section{Conclusão}

As novas formas de sociabilidade e acesso à informação reconfiguraram muitos pontos da sociedade contemporânea. Sabemos que o impacto é grande também nas arquibancadas, que muitas vezes se encontravam consideravelmente esvaziada. Os jogos são transmitidos em tempo real pelo sistema de pay-per-vieww, simultaneamente há várias partidas de um mesmo campeonato e há aqueles torcedores que preferem o aconchego do lar a ter de se deslocar pela cidade, frequentando estádios em horários tardios para ver seus times. Essas constatações poderiam se desdobrar em um trabalho sobre a cultura do consumo no futebol, mas não é o nosso caso e possivelmente algumas pesquisas quantitativas já estejam em andamento. Porém, vale ressaltar que as narrativas encontradas neste trabalho são antes de tudo fruto de uma experiência vivida dentro dos estádios. Com alegrias, tristezas, provocações e sentimentos que tão somente a participação e a vivência podem dar aos torcedores.

Se no Brasil uma modernização capitalista dos espaços populares de fato existe, ela não é tão capaz de tolher toda a mágica popular do futebol. Ao acompanhar todas as experiências dos torcedores, pudemos observar e crer na reinvenção dos próprios espaços do torcer, pois mesmo modificados, com as diferenciações dos próprios espaços entre os torcedores, o ato de torcer é ressignificado pelos indivíduos. Não havendo a possibilidade da chamada carnavalização das arquibancadas, os torcedores fazem de 
outra forma: cantam, se põem de pé, se utilizam das próprias cadeiras do estádio para fazer ruídos. Procuram os locais dos ingressos "mais baratos" a fim de permanecerem com sua torcida. Se proibidos de adentrar ao estádio com símbolos de uma determinada torcida, como ocorre constantemente por motivos de violência no estádio, eles se fazem presentes da mesma forma, vestindo as cores do time, mas dentro do estádio fazem as mesmas menções às suas agremiações torcedoras que são primordiais para o avivamento das arquibancadas.

O estádio de futebol é de fato ainda muito simbólico para todo torcedor. Mesmo com as constantes descaracterizações que atingiram sim o modus torcedor de outrora, ele ainda é uma peça importante para o futebol brasileiro. Hoje, ele se faz memória. O estádio refeito para a Copa do Mundo 2014 já não pode ser chamado de "o Colosso do Derby", muito menos de “o maior do mundo". Essas alcunhas não serão mais encontradas nos jornais do nosso tempo. Elas ficaram no período pré-Copa. A cidade olímpica é também a cidade da exclusão, o que é uma contradição, já que "reza o senso comum", ser o esporte o agregador de valores e de cidadania.

\section{Referências}

AGIER, Michel. Antropologia da cidade: lugares, situações, movimentos. São Paulo: Terceiro Nome, 2011.

AGOSTINO, Gilberto. Futebol, mundialização e mídia. In: Vencer ou morrer: futebol, geopolítica e identidade nacional. Rio de Janeiro: Mauad, 2002. p. 263-272.

AIDAR, Antonio Carlos Kfouri. O torcedor como cliente: uma solução para aumentar a receita dos clubes brasileiros. Cadernos FGV Projetos. Dossiê Futebol e desenvolvimento econômico social. São Paulo. no 13, p.30-37, 2010.

ALVITO, Marcos. A rainha de chuteiras. Um ano de futebol na Inglaterra. São Paulo: [s. n], 2013.

. A madeira da lei: gerir ou gerar a violência nos estádios brasileiros. In: BUARQUE DE HOLLANDA, Bernardo (Org). Hooliganismo e Copa de 2014. Rio de Janeiro: 7letras, 2014. p.37-53. 
APPADURAI, A. A vida social das coisas: as mercadorias sob perspectiva cultural. Niterói: EdUFF, 2008.

BAGGIO, Luiz Fernando. A enciclopédia das Copas do Mundo. 2.ed. Rio de Janeiro: Nova Terra, 2013.

BARRETO, Túlio Velho. Os espaços físicos e o habitus dos torcedores brasileiros em estádios de futebol: o que pode mudar com a adoção do "padrão FIFA"para a Copa de 2014? ANPOCS, 2011.

BOTELHO, André Ricardo M. Da Geral à Tribuna, da redação ao espetáculo: a imprensa esportiva e a popularização do futebol (1900-1920). In: SILVA, Francisco Carlos Teixeira da (Org.) Memória social dos esportes. Futebol e política: a construção de uma identidade nacional. Rio de Janeiro: Mauad X, 2006. p.313-335.

BOURDIEU, Pierre. O poder simbólico. Rio de Janeiro: Bertrand Brasil, 2006.

BUARQUE DE HOLLANDA, Bernardo. O clube como vontade e representação. O jornalismo esportivo e a formação das torcidas organizadas de futebol no Rio de Janeiro. Rio de Janeiro: 7letras, 2010.

. Torcidas, ultras e hooligans: paralelos da problemática torcedora no Brasil e na França. In: . (Org). Hooliganismo e Copa de 2014. Rio de Janeiro: 7letras, 2014. p. 145-158.

CÂMARA DOS DEPUTADOS. Lei geral da Copa. Brasília: Edições Câmara, 2012.

CASTAÑO PEREZ, Guillermo Alonso. Barra bravas en el fútbol: consumo de drogas y violência. Bogotá: Funlam, 2014.

COSTA, Maurício da Silva Drumond da. Os gramados do Catete: futebol e política na Era Vargas (1930-1945). In: SILVA, Francisco Carlos Teixeira da (Org.) Memória social dos esportes. Futebol e política: a construção de uma Identidade Nacional. Vol. 2. Rio de Janeiro: Mauad X, 2006. p.107-132.

CURI, Martin. A disputa pelo legado em megaeventos esportivos no Brasil. Horizontes Antropológicos. n. 40. p. 65-88, 2013. 
DAMO, Arlei Sander. O Brasil no horizonte dos megaeventos esportivos de 2014 e 2016: sua cara, seus sócios e seus negócios. Horizontes Antropológicos. n. 40. p. 19-63, 2013.

DARDOT, P.; LAVAL, C. A nova razão do mundo: ensaio sobre a sociedade neoliberal. São Paulo: Boitempo, 2016.

DEBORD, Guy. A sociedade do espetáculo. Comentários sobre a sociedade do espetáculo. Rio de Janeiro: Contraponto, 1997.

ELIAS, Norbert. A busca da excitação. Lisboa: Diffel, 1992.

FIFA. Fédération Internacionale de Football Association. Estádios de futebol. Recomendações e requisitos técnicos. 5. ed. 2011.

FOER, Franklin. Como o futebol explica o mundo. Um olhar inesperado sobre a globalização. Rio de Janeiro: Jorge Zahar, 2005.

GEERTZ, Clifford. A interpretação das Culturas. Rio de Janeiro: LTC, 1989.

GASTALDO, Édison. "O complô da torcida": futebol e performance masculina em bares. Horizontes antropológicos. n. 24, p.107-123, 2005.

GAFFNEY, Christopher. Mega-events and sócio-spatial dynamics in Rio de Janeiro. Journal of latin american geography. n.1, v.9, p. 7-29, 2010.

GALEANO, Eduardo. Futebol ao sol e à sombra. Porto Alegre: L\&PM, 2012.

GIULIANOTTI, Richard. Sociologia do futebol. Dimensões históricas e socioculturais do esporte das multidões. São Paulo: Nova Alexandria, 1999.

HARVEY, David. A produção capitalista do espaço. São Paulo: Annablume, 2001.

HOBSBAWM, Eric.(Org.). A invenção das tradições. São Paulo: Paz e Terra, 1997.

HOLANDA, Frederico. O espaço de excę̧ão. Brasília: UNB, 2002.

JESUS, Gilmar Mascarenhas de. Construindo a cidade moderna: a introdução dos esportes na vida urbana do Rio de Janeiro. Estudos históricos. n. 23, v. 13, p. 17-39, 1999. 
. 2014 e o desenhar conflituoso de uma nova geografia do futebol. In: SÁNCHEZ, Fernanda (Org). A Copa do Mundo e as cidades. Políticas, projetos e resistências. Niterói: Ed. UFF, 2014, p. 61-78.

LIMONAD, Ester. Estranhos no paraíso (de Barcelona). Impressões de uma geógrafa e arquiteta brasileira residente em Barcelona. Revista geográfica de Geografía y Ciencias Sociales, 2005, v. 10, no 610. Disponível em: http:/www.ub.edu/geocrit/b3w-610.htm. Acesso em: 22 ago. 2014.

MAGALHÃES, Alexandre. O "legado" dos megaeventos esportivos: a reatualização da remoção de favelas no Rio de Janeiro. Horizontes Antropológicos, 2013, Porto Alegre, p.89-118, ano 19, n. 40, 2013.

MOURA, Gisella de Araújo. O Rio corre para o Maracanã. Rio de Janeiro: FGV, 1998.

MURAD, Maurício. A violência no futebol. São Paulo: Benvirá, 2012.

. A violência e o futebol: dos estudos clássicos aos dias de hoje. Rio de Janeiro: Ed. FGV, 2007.

PEARSON, Geoff. An Ethnography of English Football Fans: cans, cops and carnivals. Manchester: Manchester University Press, 2012.

PINTO, Maurício Rodrigues. Torcidas queer e livres em campo: sexualidade e novas práticas discursivas no futebol. Ponto Urbe. n.14, p.1-11, 2014.

PRONI, Marcelo Weishaupt. A metamorfose do futebol. Campinas: Unicamp, 2000.

SIMMEL, Georg. Sociabilidade: um exemplo da sociologia pura ou formal. In: MORAES FILHO, Evaristo de. Simmel. São Paulo: Ática, 1993.

. As grandes cidades e a vida do espírito. In Revista Mana, no 11, vol. 2. p. 577 a 591, Rio de Janeiro, 2005.

TEIXEIRA, Rosana da Câmara. Os perigos da paixão. Visitando jovens torcidas cariocas. São Paulo: Annablume, 2003.

WISNIK, José Miguel. Veneno remédio: o futebol e o Brasil. São Paulo: Companhia das Letras, 2008. 